\title{
ANALISIS KESULITAN BELAJAR SISWA DALAM PEMBELAJARAN TENTANG BAKTERI
}

\section{ANALYSIS OF STUDENTS LEARNING DIFFICULTIES IN LEARNING ABOUT BACTERIA}

\author{
Nurhidayanti, Syachruddin AR dan Kusmiyati \\ Program Studi Pendidikan Biologi FKIP Universitas Mataram, Mataram, Indonesia \\ Email: nurhidayanti774@gmail.com
}

Diterima: 13 Agustus 2020. Disetujui: 15 Agustus 2020. Dipublikasikan: 30 September 2020

\begin{abstract}
Abstrak: Penelitian ini bertujuan untuk mengetahui kesulitan belajar siswa dan faktor-faktor penyebab kesulitan dalam pembelajaran tentang bakteri pada kelas X SMA Muhammadiyah Mataram. Populasi dalam penelitian ini adalah seluruh siswa kelas X SMA Muhammadiyah Mataram. Tehnik pengambilan sampel purposive sampling. Instrumen penelitian ini menggunakan tes objektif dan kuesioner. Hasil analisis kesulitan belajar memperoleh 1 siswa pada kategori sangat sulit, 4 siswa pada kategori sulit, 7 siswa pada kategori cukup sulit, 1 siswa kategori kurang sulit, dan 1 siswa pada kategori tidak sulit dengan rata-rata pada kategori cukup sulit. Hasil analisis faktor penyebab kesulitan belajar siswa diperoleh faktor internal pada kategori tidak sulit sedangkan faktor ekternal pada kategori kurang sulit. Hasil analisis kategori dengan indikator penyebab kesulitan belajar pada faktor internal diperoleh motivasi belajar tidak sulit, minat belajar kurang sulit dan perhatian belajar sulit. Faktor eksternal diperoleh sumber belajar tidak sulit, metode/strategi mengajar guru kurang sulit dan kondisi belajar kurang sulit. Oleh karena itu, faktor penyebab kesulitan belajar siswa dalam pembelajaran tentang bakteri disebabkan oleh kondisi belajar siswa, sehingga dapat disimpulkan bahwa kesulitan belajar siswa dalam pembelajaran tentang bakteri di kelas X SMA Muhammadiyah Mataram dikategorikan cukup sulit sedangkan faktor penyebab kesulitan belajar didominasi oleh faktor eksternal yang meliputi kondisi belajar.
\end{abstract}

Kata kunci: kesulitan belajar, materi bakteri

\begin{abstract}
This study aims to determine student learning difficulties and the factors that cause difficulties in learning about bacteria of class X Muhammadiyah Mataram High School. Population in research is all students of class X Muhammadiyah Mataram High School. The sampling technique was by purposive sampling. The research instrument used objective tests and questionnaires. The results of the analysis of learning difficulties get 1 student in the very difficult category, 4 students in the difficult category, 7 students in the quite difficult category, 1 student in the less difficult category, and 1 student in the not difficult category with an average in the quite difficult category. The results of the analysis of the factors causing student learning difficulties found that internal factors in the category were not difficult while external factors were in the less difficult category. The results of category analysis with indicators of the causes of learning difficulties on internal factors obtained that learning motivation was not difficult, interest in learning was less difficult and attention to learning was difficult. External factors obtained by learning resources are not difficult, teaching methods /strategies for teachers are less difficult and learning conditions are less difficult. Therefore, the factors that cause students 'learning difficulties in learning about bacteria are caused by students' learning conditions, so it can be concluded that the learning difficulties of students in learning about bacteria in class X Muhammadiyah Mataram High School are categorized quite difficult while the causative factors learning difficulties are dominated by external factors which include learning conditions.
\end{abstract}

Keywords: learning difficulties, bacterial material.

\section{PENDAHULUAN}

Pendidikan adalah unsur sadar yang bertujuan untuk mengembangkan kualitas manusia sebagai suatu kegiatan yang sadar akan tujuan, sehingga dalam pelaksanaannya berada dalam suatu proses yang berkesinambungan untuk setiap jenis dan jenjang pendidikan, semuanya berkaitan dalam suatu pendidikan yang bersifat internal [1]. Pendidikan memegang peranan yang sangat penting dalam kelangsungan hidup suatu bangsa, karena dari tujuan pendidikan ialah menyediakan lingkungan yang memungkingkan anak didik untuk mengembangkan bakat dan kemampuangnya secara optimal, sehingga ia dapat mewujudkan dirinya dan berfungsi sepenuhnya sesuai dengan kebutuhan pribadinya dan kebutuhan masyarakatnya [2].

Pembelajaran memiliki dua aspek penting yaitu aspek hasil belajar yakni perubahan perilaku pada diri siswa dan aspek proses belajar yakni sejumlah pengalaman intelektual, emosional, dan fisik pada diri siswa [3]. Pembelajaran yang menimbulkan interaksi belajar-mengajar antara guru dan siswa medorong perilaku belajar siswa. Siswa merupakan kunci terjadinya perilaku belajar dan ketercapaian sasaran belajar. Sehingga bagi siswa pelaku belajar merupakan proses belajar yang 
dialami dan dihayati sekaligus merupakan aktivitas belajar tentang bahan belajar dan sumber belajar dilingkungannya. Bagi siswa, dalam kegiatan belajar tersebut ada tiga tahap, yaitu tahap sebelum belajar, kegiatan selama proses belajar, dan kegiatan setelah belajar.

Guru sebagai pendidik bertugas untuk membantu siswa agar mendapatkan pengetahuan dan keterampilan yang baik terhadap konsep-konsep dan prinsip-prinsip ilmu pengetahuan untuk memudahkan mereka mempelajari ilmu pengetahuan dikelas yang tinggi. Proses pembelajaran Biologi yang dilakukan oleh guru hendaknya memungkinkan terjadinya pengembangan pemahaman konsep, sikap, dan memungkinkan minat siswa terhadap pembelajaran biologi. Kenyataannya para pelajar seringkali tidak mampu mencapai tujuan belajarnya atau tidak memperoleh perubahan tingkah laku sebagaimana yang diharapkan. Sementara itu, setiap siswa dalam mencapai sukses belajar, mempunyai kemampuan yang berbeda-beda. Ada siswa yang dapat memcapainya tanpa kesulitan, akan tetapi banyak pula siswa yang mengalami kesulitan, sehingga menimbulkan masalah bagi perkembangan pribadinya. Ini berarti bahwa berhasil atau kegagalan pencapaian tujuan pendidikan itu amat tergantung pada proses belajar yang dialami siswa, baik ketika ia berada di sekolah maupun dilingkungan rumah atau di lingkungan keluarga.

Salah satu tanda atau gejala siswa yang memiliki kesulitan belajar adalah rendahnya prestasi belajar dari siswa, dengan kata lain nilai yang dicapainya di bawah rata-rata nilai KKM [4]. Berdasarkan pemangamat penulis dan hasil wawancara dengan Bapak Imam Gunawan S.Pd, guru Biologi SMA Muhammadiyah Mataram, masih banyak diantara siswa tersebut yang mendapatkan nilai rendah yang masih jauh berada dibawah kriteria ketuntasan minimal (KKM) berdasarkan ketetapan atau patokan yang diambil oleh guru mata pembelajaran Biologi sekolah tersebut, yaitu sebesar 75. Menurut hasil belajar ini dapat dilihat dari rendahnya hasil latihan, baik latihan di kelas maupun pekerjaan rumah atau tugas-tugas rumah yang diselasaikan tidak tepat waktu dan menurunya hasil ulangan harian atau post test yang ditandai dengan diperolehnya nilai-nilai yang rendah. Berdasarkan hal-hal diatas mengasumsikan sebagai faktor-faktor penyebab kesulitan dalam belajar bahasa ilmiah yang dialami oleh siswa yang dapat diartikan sebagai kesukaran siswa dalam menerima atau menyerap pelajaran pada konsep bakteri di sekolah.

Berdasarkan uraian diatas, penulis tertarik melakukan penelitian mengenai kesulitan belajar siswa, sehingga penulis mengangkat penelitian dengan judul "Analisis Kesulitan Belajar Siswa dalam pembelajaran tentang Bakteri pada kelas X di SMA Muhammadiyah Mataram Tahun 2019”.

\section{METODOLOGI}

Penelitian dilaksanakan pada pembelajaran semester ganjil tahun ajaran 2019/2020. Pengambillan data dilaksanakan dari bulan Oktober sampai November 2019. Adapun tempat penelitian yaitu di SMA Muhammadiyah Mataram.

Jenis penelitian ini adalah penelitian deskriptif, dengan populasi seluruh peserta didik kelas X di SMA Muhammadiyah Mataram yang terdiri dari 2 kelas yaitu X IPA sampai X IPS. Sampel penelitian ini diambil kelas $\mathrm{X}$ IPA. Teknik pengambilan sampel yang digunakan dalam penelitian ini yaitu purposive sampling.

Instrumen yang digunakan dalam penelitian ini adalah tes hasil belajar dan angket. Tes hasil belajar dalam bentuk tes objektif yang berjumlah 15 soal dan Angket ini disusun dengan menggunakan skala Likert yang terdiri dari pernyataan- pernyataan tertulis sebanyak 25 item.

Analisis data hasil belajar siswa dilakukan dengan menghitung siswa yang mengalami kesulitan dari soal yang diberikan, kemudian nilai yang diperoleh dikonversi dalam lima kategori kesulitan belajar (Tabel.1).

Tabel 1. Kategori kesulitan belajar

\begin{tabular}{cc}
\hline Rentang Nilai & $\begin{array}{c}\text { Kategori Kesulitan } \\
\text { Belajar }\end{array}$ \\
\hline $0-19$ & Sangat sulit \\
$20-39$ & Sulit \\
$40-59$ & Cukup sulit \\
$60-79$ & Kurang sulit \\
$80-100$ & Tidak Sulit \\
\hline
\end{tabular}

Analisis data angket siswa dilakukan dengan menghitung penyebab kesulitan belajar siswa yang diperoleh dari angket yang mencakup dua indikator faktor-faktor kesulitan belajar yaitu faktor internal dan faktor eksternal. Hasil dari analisis faktor-faktor penyebab kesulitan belajar siswa, dapat dikategorikan sebagai berikut (Tabel 2).

Tabel. 2 Kategori Faktor-Faktor Penyebab Kesulitan Belajar Siswa

\begin{tabular}{cc}
\hline Skor & Kategori penyebab \\
\hline $0-19$ & Sangat Sulit \\
$20-39$ & Sulit \\
$40-59$ & Kurang Sulit \\
$60-79$ & Tidak Sulit \\
$80-100$ & Sangat tidak Sulit \\
\hline
\end{tabular}

\section{HASIL DAN PEMBAHASAN}

Hasil analisis tes objektif kesulitan belajar siswa dalam mempelajari materi bakteri dapat terangkum pada table 3 . 
Tabel 3. Data Hasil Belajar

\begin{tabular}{ccc}
\hline Jumlah siswa & $\begin{array}{c}\text { Nilai hasil } \\
\text { belajar }\end{array}$ & $\begin{array}{c}\text { Kategori Kesulitan } \\
\text { Belajar }\end{array}$ \\
\hline 1 siswa & 13 & Sangat sulit \\
4 siswa & 33 & Sulit \\
7 siswa & 53 & Cukup sulit \\
1 siswa & 60 & Kurang sulit \\
1 siswa & 80 & Tidak Sulit \\
Rata-Rata & 42 & Cukup sulit \\
\hline
\end{tabular}

Pada Tabel 3 menunjukkan bahwa kesulitan belajar siswa pada materi bakteri yang diperoleh dari tes objektif yang diberikan pada siswa kelas X IPA yang terdiri dari 14 orang siswa memperoleh nilai rata-rata 42 yang dikategorikan cukup sulit. Pembelajaran tentang bakteri ini adalah materi yang dianggap paling sulit oleh siswa yang terbukti dari hasil tes individu pada materi bakteri hanya 1 siswa memperoleh nilai yang tertinggi yaitu 80 (terdapat pada tabel 3). Hal ini membuktikan bahwa siswa mengalami kesulitan belajar dalam pembelajaran tentang bakteri. Sejalan dengan Burton dalam Idris [5] menyatakan bahwa siswa dikatakan mengalami kesulitan belajar ditunjukkan oleh adanya kegagalan siswa dalam mencapai tujuan pembelajaran, seperti batas waktu tertentu yang bersangkutan tidak mencapai tinggi kerberhasilan atau tingkat penguasan materi minimal dalam pembelajaran tertentu yang telah ditetapkan oleh guru.

Selain data di atas, peneliti juga mendapatkan data faktor-faktor penyebab kesulitan belajar siswa dari kuesioner/angket yang telah diisi oleh siswa kelas X IPA. Faktor-faktor penyebab kesulitan belajar terdiri dari faktor internal dan faktor eksternal. Data faktor dapat dilihat pada tabel 4.

Tabel 4 Data Faktor Kesulitan Belajar Dalam Pembelajaran Tentang Bakteri

\begin{tabular}{ccc}
\hline Faktor & Nilai & Kategori \\
\hline Internal & 60 & Tidak Sulit \\
Eksternal & 57 & Kurang Sulit \\
\hline
\end{tabular}

Tabel 4 di atas menunjukkan bahwa nilai faktor internal (60) lebih besar dari pada faktor eksternal (57), hal ini menunjukkan bahwa faktor yang mempengaruhi penyebab kesulitan belajar siswa terdapat pada faktor eksternal. Hasil penelitian ini sejalan dengan temuan Umiyati dan Susilo[6] bahwa faktor eksternal juga yang menyebabkan kesulitan belajar biologi pada materi virus siswa kelas X.7 di SMA Negeri 1 Sukagumiwang.

Hasil analisis masing-masing indikator penyebab kesulitan belajar siswa dapat terangkum pada Tabel 5.

Berdasarkan data yang diperoleh (pada tabel 5), kesulitan belajar yang dialami siswa pada materi bakteri disebabkan oleh: (1) faktor ekternal yang meliputi indikator minat belajar memperoleh nilai 54.52 yang diaktegorikan kurang sulit. Kurang sulit yang dimaksudkan disini adalah sebagian siswa yang mengalami kesulitan belajar dalam pembelajaran tentang bakteri. Minat terhadap pelajaran dapat dilihat dari cara siswa dalam mengikuti pelajaran, kelengkapan dalam mencatat penjelasan guru, dan perhatian terhadap pelajaran [7]. (2) faktor eksternal yang meliputi kondisi belajar memperoleh nilai 45.00 yang dikategorikan kurang sulit, hal ini menyatakan bahwa kondisi belajar dapat mempengaruhi faktor penyebab kesulitan belajar siswa dalam pembelajaran tantang bakteri pada kelas X di SMA Muhammadiyah Mataram. Sejalan dengan Prayogo dalam okxy [8] yang menyatakan bahwa penyebab kesulitan belajar siswa yang paling dominan dari faktor eksternal yaitu kondisi belajar. Menurut Ahmadi dan Supriyono [9], faktor ini berhubungan dengan kondisi kelas, pencahayaan kelas, ventilasi, dan juga alat pendukung. Selain itu, penjadwalan biologi tentang materi bakteri yang dijadwalkan pada jam terakhir. Hal ini dapat mempengaruhi konsentrasi siswa dalam menyerap pembelajaran biologi terutama materi bakteri. Kondisi ini telah terjadi pada proses belajar yang ditandai oleh adanya hambatan tertentu untuk mencapai hasil belajar. Hambatan tersebut mungkin disadari atau tidak disadari oleh siswa, mungkin bersifat psikologis, sosiologis, ataupun fisiologis dalam proses belajarnya. Sejalan dengan Hamalik [10,11] yang menyatakan bahwa sulit atau tidaknya proses belajar yang diikuti siswa dipengaruhi oleh kondisi lingkungan yang diciptakan dalam proses belajar mengajar. Proses belajar mengajar yang tidak diikuti oleh pengendalian siswa atau sarana belajar yang baik, dapat menyebabkan kondisi belajar yang tidak mampu diciptakan secara optimal yang berakibat tidak tercapainya tujuan pembelajaran yang diinginkan. Jadi, dalam lingkungan belajar diperlukan pengendalian siswa dan sarana belajar agar terciptanya kondisi belajar yang menyenangkan guna membatu siswa dalam mencapai tujuan belajar. Hadiningsih [12] menyatakan bahwa kondisi belajar yang optimal dapat tercapai jika guru mampu mengatur siswa dan sarana pengajaran serta mengendalikannya dalam suasana yang menyenangkan agar siswa dapat mencapai tujuan pembelajaran. 
Tabel 5 Data Tentang Faktor-Faktor penyebab Kesulitan Belajar

\begin{tabular}{cccc}
\hline Faktor & Indikator & Nilai & Kategori \\
\hline \multirow{3}{*}{ Internal } & Motivasi Belajar & 67.50 & Tidak sulit \\
& Minat Belajar & 54.52 & Kurang sulit \\
& Perhatian Belajar & 60.00 & Tidak sulit \\
\hline \multirow{3}{*}{ Eksternal } & Sumber Belajar & 70.00 & Tidak sulit \\
& Metode Strategi Mengajar Guru & 50.71 & Kurang Sulit \\
& Kondisi Belajar & 45.00 & Kurang Sulit \\
\hline
\end{tabular}

\section{KESIMPULAN}

Berdasarkan hasil penelitian dan pembahasan, maka dapat diambil kesimpulan bahwa kesulitan belajar siswa dalam pembelajaran tentang bakteri di kelas X SMA Muhammadiyah Mataram yang dikategorikan cukup sulit dan faktor yang menyebabkan kesulitan belajar siswa dalam pembelajaran tentang bakteri yang dominan pada faktor eksternal terutama kondisi belajar.

\section{DAFTAR PUSTAKA}

[1] Sagala, S. (2010). Konsep dan makna pembelajaran. Bandung: alfabeta.

[2] Munandar, U. (2002). Kreativitas dan Keterbakatan Strategi Mewujudkan Potensi Kreativitas dan Bakat. Jakarta: PT. Gramedia Pustaka Utama.

[3] Dimyati, M. (2006). Belajar dan pembelajaran. Jakarta: Rineka Cipta.

[4] Djamarah, S. B. (2011). Psikologi Belajar. Jakarta: Rineka Cipta.

[5] Idris, R. (2017). Mengatasi kesulitan belajar dengan pendekatan psikologi kognitif. Lentera pendidikan: jurnal ilmu tarbiyah dan keguruan, 12(2), 152-172.

[6] Umiyati, D., \& Susilo, M. J. (2014). Perbandingan Faktor-Faktor Penyebab Kesulitan Belajar antara Siswa Kelas X. 6 dengan Kelas X. 7 pada Mata Pelajaran Biologi Materi Virus (Study Kasus di SMA N 1 Sukagumiwang-Indramayu). Jurnal Penelitian Mahasiswa-Pendidikan Biologi, 1(1), 106-108.
[7] Ahmadi, A. dan Widodo, S. (2013). Psikologi Belajar. Jakarta: Rineka Cipta

[8] Ixganda, O. (2015). Analisis Deskriptif Faktor Penyebab Kesulitan Belajar pada Mata Pelajaran Chassis dan Pemindah Daya Siswa Kelas XI Program Keahlian Teknik Kendaraan Ringan. Jurnal Pendidikan Teknik Mesin, 15(2).

[9] Ahmadi, A. dan Widodo, S. (2004). Psikologi Belajar. Jakarta: Rineka Cipta.

[10] Hamalik, O. (2009). Psikologi belajar dan mengajar. Bandung: Sinar Baru Algensindo.

[11]Zulkarnain, I., \& Farhan, M. (2020). Pengaruh Waktu Belajar Terhadap Kemampuan Koneksi Matematika Dengan Mengontrol Kemampuan Awal. Jurnal Pijar Mipa, 15(2), 145-150.

[12] Ningrum, A. S., Lestari, N., \& Kusmiyati, K. (2018). Perbedaan Hasil Belajar IPA Biologi Menggunakan Model Pembelajaran Kooperatif Tipe Team Assisted Individualization Dengan Tipe Mind Mapping Pada Siswa Kelas VII SMP Negeri 19 Mataram. Jurnal Pijar Mipa, 13(1), 37-44. 